\title{
Investigation of Relationship Between Body Mass Index and Neck Biomechanics in Healty Young Adults: A Cross-Sectional Study in a Single Center
}

\author{
Hasan Erkan KILINÇ ๑ ®, Aynur Ayşe KARADUMAN ๑ \\ Lokman Hekim University, Faculty of Health Science, Department of Physiotherapy and Rehabilitation, Ankara, Turkey \\ Cite this article as: Kılınç HE and Karaduman AA. Investigation of Relationship Between Body Mass Index and Neck Biomechanics in Healty Young Adults: A Cross-Sectional Study \\ in a Single Center. Turk J Diab Obes 2021;2: 173-179.
}

\begin{abstract}
Aim: The aim of this study is to examine the effects of body mass index above normal limits on forward head posture and deep cervical flexor muscle endurance, which are considered to be predisposing factors of mechanical neck pain.

Material and Methods: Twenty-four individuals (mean age of $20.50 \pm 2.02$ years) with a body mass index (BMI) between $19.9 \mathrm{~kg} / \mathrm{m}^{2}$ and $24.9 \mathrm{~kg} / \mathrm{m}^{2}$ were included in the Normal Body Mass Index (N-BMI group) and 24 individuals with a BMI over $24.9 \mathrm{~kg} / \mathrm{m}^{2}(\mathrm{mean}$ age of $24.41 \pm 2.90$ years) were included in the Owerweight-Obese (OW-O group). All individuals were recruited from those who scored 0-4 points from Neck Disability Index (NDI) indicating that there was no disability. Cranicervical Angles (CCA) of individuals was measured digitally to determine forward head posture. Deep Cervical Flexor Muscle Endurance Test (DCFMET) was used for endurance of deep cervical flexor muscles.

Results: The CCA values of the OW-O group were less than in the N-BMI group, indicating an increased forward head posture ( $\mathrm{p}=$ 0.043). There was no statistically significant difference in terms of the endurance of the deep cervical flexor muscles between the groups $(\mathrm{p}=0.817)$. A moderate negative correlation was found between the BMI values and CCA of all individuals participating in the study (p $=0.012, r=-0.503)$. There was no correlation between BMI and DCFMET $(\mathrm{p}=0.887, \mathrm{r}=0.316)$. A robust regression model revealed that increased BMI was significantly associated with greater CCA $(\beta=-0.554, \mathrm{p}<0.001)$.

Conclusion: Knowing that overweight and obese young people are in the risk group for mechanical neck pain and various cervical pathologies, plays a very important role in increasing awareness about preventive approaches such as postural correction exercises and weight management strategies.
\end{abstract}

Keywords: Neck pain, Obesity, Posture, Neck muscles

\section{Sağlıklı Genç Yetişkinlerde Vücut Kütle İndeksi ve Boyun Mekaniği İlişkisinin İncelenmesi: Tek Merkezli Kesitsel Bir Çalışma}

ÖZ

Amaç: Bu çalışmanın amacı, normal sınırların üzerindeki vücut kütle indeksinin, mekanik boyun ağrısına zemin hazırlayan faktörler olarak kabul edilen baş ileri pozisyonu ve derin servikal fleksör kasların enduransı üzerindeki etkilerini incelemektir.

Gereç ve Yöntemler: Vücut Kütle İndeksleri (VKİ) $19.9 \mathrm{~kg} / \mathrm{m}^{2}$ ve $24.9 \mathrm{~kg} / \mathrm{m}^{2}$ arasında olan yirmi dört birey (ortalama yaş: $20.50 \pm 2.02$ yıl) Normal Vücut Kütle İndeksi grubuna (N-VKİ grubu), Vücut Kütle İndeksleri (VKİ) $24.9 \mathrm{~kg} / \mathrm{m}^{2}$ üzerinde olan 24 birey (ortalama yaş: $24.41 \pm 2.90$ yıl) Aşırı kilolu-Obez grubuna dahil edildi (AK-O grubu). Tüm bireyler Boyun Özür İndeksinden (BÖİ) herhangi bir özür durumun olmadığını gösteren 0-4 puan aralığında alanlardan seçildi. Bu baş ileri postürünü tespit etmek için, bireylerin Kranioservikal Açıları (KSA) dijital olarak ölçüldü. Derin servikal fleksör kasların enduransını ölçmek için Derin Servikal Fleksör Kasların Endurans Testi (DSFKE) kullanıldı.

ORCID: Hasan Erkan Kılınç / 0000-0002-6629-1619, Aynur Ayşe Karaduman / 0000-0001-6252-1934 
Bulgular: AK-O grubunun KSA değerleri N-VKİ grubuna göre istatistiksel olarak daha düşüktü ( $\mathrm{p}=0.043$ ). Bu durum da artmış baş ileri postürünü işaret etmekteydi. Gruplar arasında derin servikal fleksör kasların enduransında istatistiksel olarak fark yoktu ( $\mathrm{p}=0.817$ ). Çalışmaya katılan tüm bireylerin VKİ ile KSA değerleri arasında negatif yönde orta düzey korelasyon bulundu ( $\mathrm{p}=0.012$, $\mathrm{r}=-0.503$ ). VKİ ile DSKE arasında bir korelasyon yoktu ( $\mathrm{p}=0.887, \mathrm{r}=0.316)$. Robust regresyon modeli artmış VKİ'nin daha yüksek KSA değerleri ile anlamlı düzeyde ilişkili olduğunu ortaya koydu $(B=-0.554, \mathrm{p}<0.001)$.

Sonuç: Aşırı kilolu ve obez gençlerin mekanik boyun ağrısı ve çeşitli servikal patolojiler açısından risk grubunda olduğu bilmek, postural düzgünlük egzersizleri ve kilo kontrol stratejileri gibi önleyici yaklaşımlar hakkında farkındalığın artması için çok önemli bir rol oynamaktadir.

Anahtar Sözcükler: Boyun ağrısı, Obezite, Postür, Boyun kasları

\section{INTRODUCTION}

It has been reported that the worldwide prevalence of mechanical neck pain reaches $86.8 \%$, and one out of every two people experience mechanical neck pain at least once in their life $(1,2)$. One of the main problems underlying mechanical neck pain is deterioration in neck biomechanics. Proper neck biomechanics largely depends on the longus colli and longus capitis muscles, which are called deep cervical flexor muscles. The activation and endurance deficiencies of these muscles predispose to the development of mechanical neck pain $(3,4)$. Furthermore, segmental degenerative changes that develop in addition to the impairments of balance and visual system with aging can cause mechanical originated neck pain by reducing correct postural biomechanics and muscular endurance (5). It also has been reported that increased body mass index negatively affects body biomechanics $(6,7)$.

Body mass index over $19.9 \mathrm{~kg} / \mathrm{m}^{2}$ is regarded as overweight, and over $24.9 \mathrm{~kg} / \mathrm{m}^{2}$ is obesity by World Health Organization (8). Overweight rate has been increasing rapidly in Turkey and world. The proportion of individuals whose body mass index is above normal values has increased to $66.8 \%$ in Turkey and $52.1 \%$ in the world (9).

In addition, forward head posture is quite common in etiology of cases with mechanical neck pain in all age groups. The head appears to be positioned forward in the sagittal plane and in front of the midline of the body, and this is considered the most common postural deformity $(10,11)$. This postural change is also one an important factor that predisposes to mechanical neck pain such as deep cervical muscle endurance deficiencies (12). As the head goes anteriorly, the person hyperextends the upper cervical segments to expand the field of vision and this situation increases lordosis in the cervical region. Increased cervical lordosis causes pathomechanical changes in the posterior cervical and especially nuchal muscles and thus leads up to pain. Cervicogenic headaches could also be seen due to the excessive activity of nuchal muscles.
Overweight and obesity lead to many systemic diseases and negatively affect body biomechanics (13). A problem in body biomechanics affects all segments into caudocephalic direction. For example, a pelvic asymmetry appears as temporomandibular joint dysfunction. Physiotherapy and rehabilitation primarily focuses on correcting pelvic asymmetry, not the temporomandibular region. Similarly, most of the neck problems are caused by pathomechanisms in the lower segments. However, the main factor that leads the upper body pathomechanics in people with a body mass index above normal limit is that excess adipose tissue causes dysalignment in the lower postural segments. Therefore, only trying to correct malposition in lower segments with therapeutic exercises is not very effective in treatment. We think that this first focus should be on adipose tissue, which is the main cause of the problem of posture in the lower segments. Although the negative effects of obesity and overweight on general body posture have been reported no study specifically examining and demonstrating the effects on neck biomechanics was found $(6,7)$. Studies do not emphasize enough on this important parameter in mechanical neck pain.

The aim of this study is to examine the effects of body mass index above normal limits on head anterior tilt angle and deep cervical muscle endurance, which are considered to be predisposing factors of mechanical neck pain

\section{MATERIALS and METHODS}

\section{Subjects}

This was a cross-sectional study conducted in Lokman Hekim University.

Healthy young adult volunteers between the ages of 18-30 were invited by putting up notices in various areas of the Lokman Hekim University. The height and body weights of all volunteers were measured, and then body mass indexes (BMI) of volunteers were calculated. Individuals with a BMI between $19.9 \mathrm{~kg} / \mathrm{m}^{2}$ and $24.9 \mathrm{~kg} / \mathrm{m}^{2}$ were considered as normal BMI group (N-BMI), with a BMI above $24.9 \mathrm{~kg} / \mathrm{m}^{2}$ were accepted as overweight and obese group (OW-O). 
Informed consents of all volunteers were obtained. This study was approved by the Lokman Hekim University Non-Interventional Ethics Committee (decision number: 2020/057, date: $26 / 06 / 2020$ ). The inclusion criteria comprised receiving less than 5 points from the Neck Disability Questionnaire (NDI), being with a BMI over $19.9 \mathrm{~kg} /$ $\mathrm{m}^{2}$, and being volunteer to participate in study. Participants having undergone surgery in the neck and upper extremity region, having a history of migraine, cervical disc pathology, scoliosis, and any neurological, rheumatological or systemic disease were excluded. Also participants having neck pain because of degenerative changes occurring with aging are excluded.

$\mathrm{G}^{\star}$ Power programme Version 3.1.9.7 was used to calculation of sample size. Per a previous study (14) we needed 16 individuals in each group to have $95 \%$ power with $5 \%$ type I error level. Twenty-four individuals were recruited in each group considering $33 \%$ drop out.

\section{Evaluations}

\section{Body Mass Index (BMI)}

Body weights of the individuals were measured by Body Composition Analyzer (Tanita, BC-543, USA) device and their heights were measured with a tape attached to the wall. Body mass index was calculated using this formula: $\mathrm{kg} / \mathrm{m}^{2}$

\section{Neck Disability Index (NDI)}

Turkish Version of Neck Disability Index was used for determining the pain experience and functional disability of the participants. NDI is a questionnaire of 10 questions. The questions measure the pain severity, ability for personal care, lifting weight, job capability headache intensity, concentration, quality of sleeping and driving and recreation activities. The participants can get maximum 50 points from the questionnaire. 0-4 points mean "no disability", 5-14 points mean "light disability", 15-24 points mean "moderate disability", 25-34 points mean "severe disability" and 35-50 points mean "complete disability (15).

\section{Craniocervical Angle (CCA)}

In order to determine the forward position of the head and neck, the photographic CCA angle of the individuals was measured. First, the mandible, manubrium sterni, and the spinous process of the C7 vertebra were marked with a board marker. Individuals were asked to look at the line drawn at eye level on the wall in the position that they felt most comfortable during standing in front of the wall one meter away. Then, photographs were taken from the side profile, including the tragus and the cervical $7^{\text {th }}$ vertebra. The angle between the line joining the $7^{\text {th }}$ vertebra and tragus and the horizontal line was determined digitally using
AutoCad Version 1.0 program. This angle was accepted as the anterior tilt angle of the head and recorded as CCA (16). The increase of this angle indicates a decrease in the forward head position (Figure 1).

\section{Deep cervical flexor muscles endurance}

Deep Cervical Flexor Endurance Test (DCFMET) was used for assessing the endurance of deep cervical flexor muscles (17). During this test, individuals were asked to lie in supine position with hands next to the body and legs in a hooked position at $45^{\circ}$. Then, individuals were asked to perform head retraction by slightly retracting their jaws. Therapist placed the thumb and index finger under the occiput of the individual. The individual was asked to raise the upper part of the head so that the fingers of therapist did not touch the occiput. The test was completed when the individuals felt too painful to continue to test, the jaw retraction position was lost, the individual performed neck flexion until the contact between the head and the therapist's fingers was completely lost and the superficial neck flexor muscles such as sternoclediomasteideus and anterior scalene muscle contracted. The endurance test time was recorded in seconds (Figure 2).

\section{Statistical Analysis}

Statistical analysis was performed with SPSS 20.0 software package (SPSS, Inc., Chicago, IL, USA) statistical program. The conformity of the obtained data to normal distribution was evaluated using visual (Histogram and probability graphs) and analytical methods (Kolmogorov-Smirnov

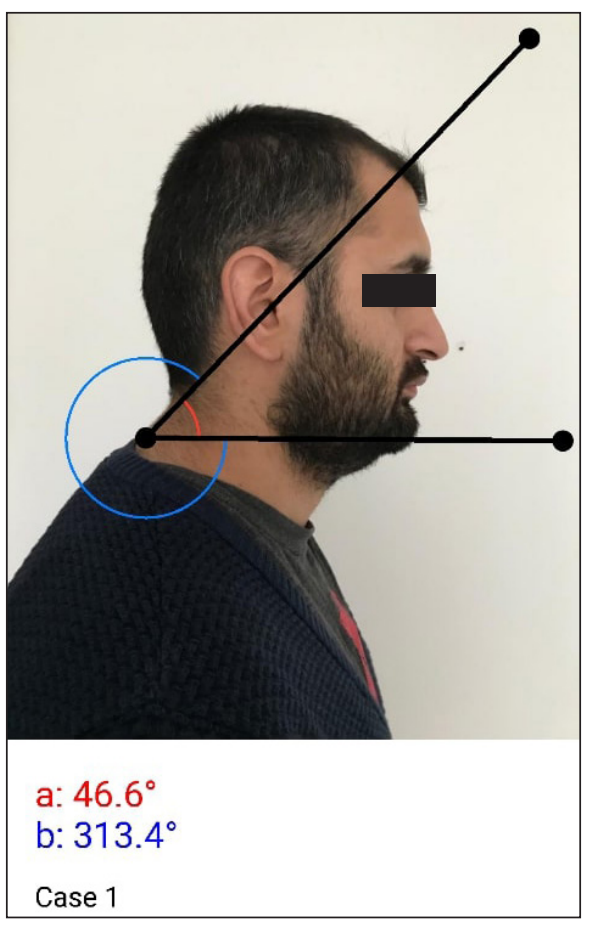

Figure 1. The increase of this angle indicates a decrease in the forward head position 
Table 1: Comparisons of the demographics and measured parameters between the groups.

\begin{tabular}{|c|c|c|c|c|}
\hline & $\begin{array}{c}\text { N-BMI }(n=24) \\
\text { Mean } \pm \text { SD }\end{array}$ & $\begin{array}{l}\text { OW }(n=24) \\
\text { Mean } \pm \text { SD }\end{array}$ & $\mathbf{p}$ & $\begin{array}{c}\text { Effect Size } \\
\text { Cohen d }\end{array}$ \\
\hline Age (years) & $20.50 \pm 2.02$ & $22.41 \pm 2.90$ & 0.211 & 0.764 \\
\hline Height $(\mathrm{cm})$ & $167.51 \pm 33.21$ & $169.44 \pm 40.21$ & 0.445 & 0.052 \\
\hline Weight (kg) & $59.23 \pm 16.43$ & $80.81 \pm 19.02$ & $0.012^{*}$ & 1.214 \\
\hline BMI $\left(\mathrm{kg} / \mathrm{m}^{2}\right)$ & $21.24 \pm 2.46$ & $28.39 \pm 2.94$ & $0.031^{\star}$ & 2.637 \\
\hline NDI (score) & $3.79 \pm 1.79$ & $3.44 \pm 1.34$ & 0.354 & 0.221 \\
\hline CCA $\left(\right.$ degree $\left.^{\circ}\right)$ & $53.12 \pm 6.39$ & $44.94 \pm 6.49$ & $\mathbf{0 . 0 4 3}^{*}$ & 1.270 \\
\hline DCFMET (sec) & $45.96 \pm 27.27$ & $50.83 \pm 30.76$ & 0.817 & 0.167 \\
\hline
\end{tabular}

${ }^{*} \mathrm{p}<0.05$, Independent Samples $\mathrm{t}$ test, BMI: Body Mass Index; NDI: Neck Disability Index;

CCA: Craniocervical Angle; DCFMET: Deep Cervical Flexor Muscle Endurance Test.

/ Shapiro-Wilk tests). Descriptive statistics were calculated as a number/percentage (n/\%) for qualitative data and mean \pm standard deviation for quantitative data. Independent samples $t$ test was used for intergroup differences. Pearson Correlation analysis was performed to determine the relationships among the CCA, BMI and DCFME . A robust regression model was used to identify whether BMI and DCFME were independent predictors of CCA.

\section{RESULTS}

Twenty-four individuals (mean age: $20.50 \pm 2.02$ years) with BMI between $19.9 \mathrm{~kg} / \mathrm{m}^{2}$ and $24.9 \mathrm{~kg} / \mathrm{m}^{2}$ were included in the N-BMI group and 24 individuals with BMI over $24.9 \mathrm{~kg} /$ $\mathrm{m}^{2}$ (mean age: $24.41 \pm 2.90$ years) were included in the OW-O group. This study has been completed with 48 healthy individuals. There were 24 males and 24 females in both groups. The comparisons of demographic data and the measured parameters in both groups were shown in Table 1.

When CCA and DCFMET values obtained from N-BMI and OW-O groups were examined, it was found that CCA values were measured at a lower value in OW-O group, indicating an increased position of the head forward $(p=0.043)$. There was no statistically significant difference between the groups in terms of the endurance of the deep cervical flexor muscles $(\mathrm{p}=0.817)($ Table 1$)$.

A moderately negative correlation was found between the BMI values and CCA of all individuals participating in the study ( $\mathrm{p}=0.012, \mathrm{r}=-0.503)$. There was no correlation between BMI and DCFMET ( $\mathrm{p}=0.887, \mathrm{r}=0.316)$. Also no correlation was found between CCA and DCFMET $(\mathrm{p}=0.432, \mathrm{r}=-0.115)$ (Table 2).

Robust regression analyses indicated that $\mathrm{BMI}$ was uniquely associated with CCA $(\beta=-0.554, \mathrm{p}<0.001)$ (Figure 3$)$. DCFMET was not significantly associated with CCA $(p>0.05)$ (Table 3).

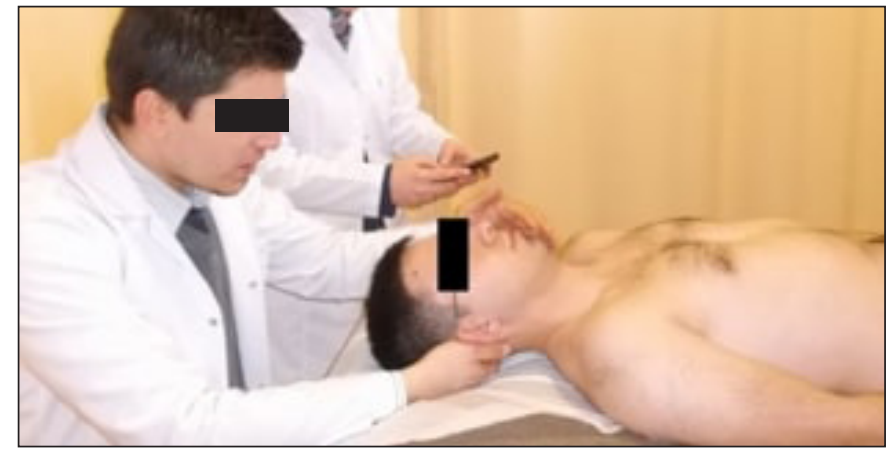

Figure 2. The endurance test time

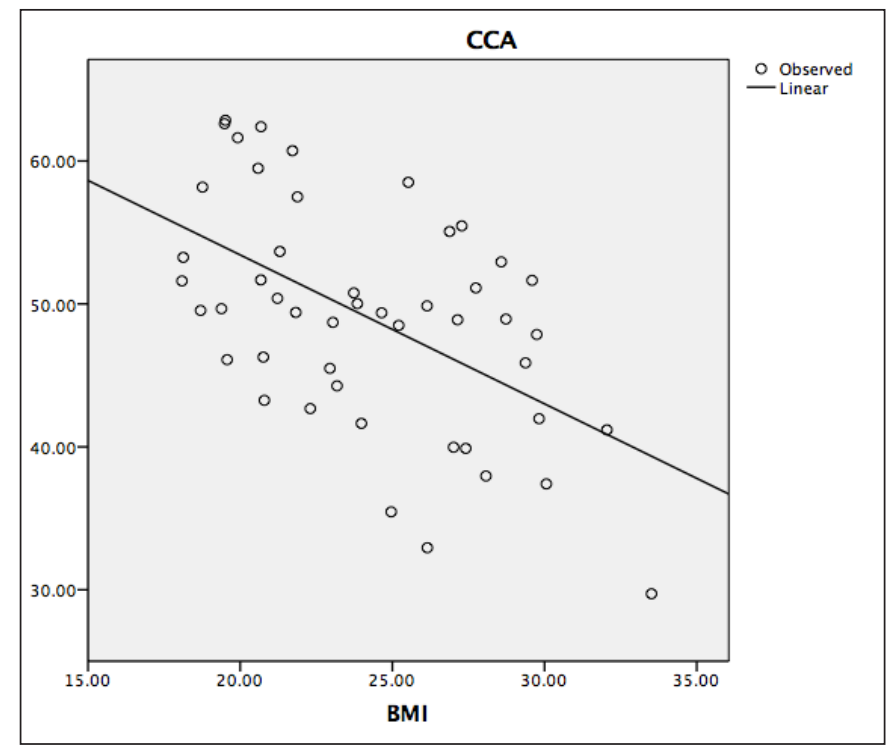

Figure 3. Curve estimation graphic among CCA and BMI

\section{DISCUSSION}

The present study with the exclusion of degenerative changes occurring with age investigated the effects of the increase in BMI on the deep cervical flexor muscle endur- 
Table 2: Pearson correlational coefficients for associations among the CCA, BMI and DCFMET

\begin{tabular}{|c|c|c|c|c|c|c|}
\hline \multirow[b]{2}{*}{ CCA } & \multicolumn{2}{|c|}{ CCA } & \multicolumn{2}{|c|}{ BMI } & \multicolumn{2}{|c|}{ DCFMET } \\
\hline & & & ${ }^{*} \mathrm{p}=0.012$ & $\mathrm{r}=0.503$ & $\mathrm{p}=0.432$ & $\mathrm{r}=-0.115$ \\
\hline BMI & ${ }^{*} \mathrm{p}=0.012$ & $\mathrm{r}=0.503^{\star}$ & & & $\mathrm{p}=0.887$ & $\mathrm{r}=0.316$ \\
\hline DCFMET & $\mathrm{p}=0.432$ & $\mathrm{r}=-0.115$ & $\mathrm{p}=0.887$ & $\mathrm{r}=0.316$ & & \\
\hline
\end{tabular}

Table 3: Robust Regression analysis with CCA as the dependent variable.

\begin{tabular}{lcc}
\hline Variables & Standardised $\boldsymbol{\beta}$ & $\mathbf{t}$ \\
\hline BMI & -0.554 & $-4.186^{*}$ \\
\hline DCFMET & 0.061 & 0.460 \\
\hline
\end{tabular}

${ }^{*} \mathrm{p}<0.001$

ance and head and neck position, which are considered to be predisposing factors for neck pain. The results of present study showed that CCA values were measured at a lower value, indicating an increased forward position of the head in individuals classified as overweight and obese according to BMI values compared to individuals with normal BMI. A negative correlation was found between BMI and CCA values in all participants. Furthermore, it was seen that BMI affecting CCA regression analysis.

Body mass index above normal limits also means the increase in subcutaneous adipose tissue. This adipose tissue also adversely affects the spinal column biomechanics as it creates an additional load on the segments of the body that are exposed to gravitational forces(1). The fat deposits in the abdominal area cause the forward shift of center of gravity, resulting in increased lumbar lordosis. An increase in thoracic kyphosis and cervical lordosis is also observed due to the interconnected segmental structure of the vertebral column sagittal curvatures. With an increase of thoracic kyphosis and cervical lordosis, the anterior tilt of the head also increases $(18,19)$. Compared to individuals with normal BMI, the decrease in CCA values of individuals with high BMI values and correlations between parameters can be considered as statistical results demonstrating this situation.

According to the results obtained from the present study, there was no statistical difference in deep cervical flexor muscle endurance between the groups, and no correlation was found between BMI and DCFMET data. It has been shown that the decrease in the endurance of deep cervical flexor muscles consisting of $\mathrm{M}$. longus colli and $\mathrm{M}$. longus capitis is among the main causes of mechanical neck pain $(4,20,21)$. The reasons for the absence of significant differences of the endurance of deep cervical flexor muscles between the groups and the lack of correlation between BMI and DCFMET may be due to the exclusion of individuals with neck pain and the insufficient sample size. Furthermore, it is stated that the decrease in the endurance of $\mathrm{M}$. longus colli and M. longus capitis increases with age (22). Since the present study aimed to reveal the effects of the increased body weight on cervical biomechanics by eliminating degenerative vertebral changes and muscle endurance losses occurring with age, the fact that the participants consisted of young individuals could be considered as another reason.

The results of the present study showed that the increase in BMI negatively affects the head and neck posture. Considering that the increased anterior tilt of the head plays a role as a predisposing factor for mechanical neck pain, it can be said that the individuals participating in this study are in the risk group for future cervical pathologies. The increase in body mass, which is especially seen among childhood and youth problems in the world population, prevents the protection of social health due to systemic diseases and problems related to inactivity. In present study, the negative relationship between the increase in BMI and neck biomechanics is important in terms of drawing attention to a different result of increased body weight. Nowadays, it is known that the time spent at the desk work has been increasing (23). Increased body weight as a result of overnutrition and inadequate energy expenditure due to inactivity causes chronic postural disorders, mechanical and degenerative spinal changes that may occur in young adults (24). This situation has enabled physiotherapists to focus on preventive studies for these possible changes. In addition, it is thought that the regular assessments of posture, the neck position and deep cervical muscle endurance may be important in terms of predicting possible problems in overweight and obese individuals.

The fact that this study was not designed as a comparative study in which cases from different age groups were included with a larger sample size, and that the head and neck position were not evaluated by more objective method such as radiographic measurement are considered as the limitations of the present study. 
According to the results of this study, in which the effects of the increase in BMI on the head and neck position and deep cervical flexor muscle endurance in healthy young adults were examined, craniocervical angle values in individuals with high BMI indicates the increased forward position of the head. This result is important in terms of drawing attention to the importance of postural awareness and the protective, preventive and therapeutic physiotherapy and rehabilitation approaches in young and overweight individuals.

Acknowledgement

None.

\section{Authorship Contributions}

Concept: Hasan Erkan Kilinç, Aynur Ayşe Karaduman, Design: Hasan Erkan Kilinç, Data Collection or Processing: Hasan Erkan Kilinç, Analysis or Interpretation: Hasan Erkan Kilinç, Aynur Ayşe Karaduman, Literature Search: Hasan Erkan Kilinç, Writing: Hasan Erkan Kilinç.

\section{Conflict of Interest}

No conflict of interest was declared by the authors.

Financial Disclosure

The authors declared that this study received no financial support.

\section{Ethic Approval}

The experimental protocol of the study was approved by the Lokman Hekim University Non-Invasive Clinical Research Ethics Committee (2020/057).

Peer Review Process

Externally and extremely peer reviewed.

\section{REFERENCES}

1. Hoy DG, Protani M, De R, Buchbinder R. The epidemiology of neck pain. Best Pract Res Clin Rheumatol. 2010;24:783-792.

2. Genebra CVDS, Maciel NM, Bento TPF, Simeão SFAP, Vitta A. Prevalence and factors associated with neck pain: A population-based study. Braz J Phys Ther. 2017;21:274-280.

3. O'Leary S, Falla D, Jull G. The relationship between superficial muscle activity during the cranio-cervical flexion test and clinical features in patients with chronic neck pain. Man Ther. 2011;16:452-455.

4. Blomgren J, Strandell E, Jull G, Vikman I, Röijezon U.Effects of deep cervical flexor training on impaired physiological functions associated with chronic neck pain: A systematic review. BMC Musculoskelet Disord. 2018;19:415.

5. Montero-Fernandez N, Serra-Rexach JA. Role of exercise on sarcopenia in the elderly. Eur J Phys Rehabil Med. 2013;49:131143.
6. Yusuf E, Bijsterbosch J, Slagboom PE, Rosendaal FR, Huizinga TW, Kloppenburg M. Body mass index and alignment and their interaction as risk factors for progression of knees with radiographic signs of osteoarthritis. Osteoarthritis Cartilage. 2011;19(9):1117-1122.

7. Westlake CG, Milner CE, Zhang S, Fitzhugh EC. Do thigh circumference and mass changes alter knee biomechanics during walking? Gait Posture. 2013;37(3):359-362.

8. Borga M, West J, Bell JD, Harvey NC, Romu T, Heymsfield SB, Dahlqvist Leinhard O. Advanced body composition assessment: From body mass index to body composition profiling. J Investig Med. 2018;66:1-9.

9. Global Health Observatory (GHO) data: World Health Organisation 2020 [Available from: https://www.who.int/gho/ ncd/risk factors/overweight/en/.

10. Cho CY. Survey of faulty postures and associated factors among Chinese adolescents. J Manipulative Physiol Ther. 2008;31:224-229.

11. Lauche R, Wayne PM, Fehr J, Stumpe C, Dobos G, Cramer H.Does postural awareness contribute to exercise-induced improvements in neck pain intensity? A secondary analysis of a randomized controlled trial evaluating Tai Chi and neck exercises. Spine (Phila Pa 1976). 2017;42:1195-1200.

12. Paksaichol A, Janwantanakul P, Purepong N, Pensri P, van der Beek AJ. Office workers' risk factors for the development of non-specific neck pain: A systematic review of prospective cohort studies. Occup Environ Med. 2012;69:610-618.

13. Bosco C, Zanon S, Rusko H, Dal Monte A, Bellotti P, Latteri F, Candeloro N, Locatelli E, Azzaro E, Pozzo R.The influence of extra load on the mechanical behavior of skeletal muscle. Eur J Appl Physiol Occup Physiol. 1984;53:149-154.

14. Lau KT, Cheung KY, Chan KB, Chan MH, Lo KY, Chiu TT. Relationships between sagittal postures of thoracic and cervical spine, presence of neck pain, neck pain severity and disability. Man Ther. 2010;15(5):457-462.

15. Telci EA, Karaduman A, Yakut Y, Aras B, Simsek IE, Yagli N. The cultural adaptation, reliability and validity of neck disability index in patients with neck pain: A Turkish version study. Spine (Phila Pa 1976). 2008;33:E362-365.

16. Lau HM, Chiu TT, Lam TH. Measurement of craniovertebral angle with Electronic Head Posture Instrument: Criterion validity. J Rehabil Res Dev. 2010;47:911-918.

17. Olson LE, Millar AL, Dunker J, Hicks J, Glanz D. Reliability of a clinical test for deep cervical flexor endurance. J Manipulative Physiol Ther. 2006;29:134-138.

18. Maciałczyk-Paprocka K, Stawińska-Witoszyńska B, Kotwicki T, Sowińska A, Krzyżaniak A, Walkowiak J, KrzywińskaWiewiorowska M. Prevalence of incorrect body posture in children and adolescents with overweight and obesity. Eur J Pediatr. 2017;176:563-572.

19. Son SM. Influence of obesity on postural stability in young adults. Osong Public Health Res Perspect. 2016;7:378-381. 
20. Iqbal ZA, Rajan R, Khan SA, Alghadir AH. Effect of deep cervical flexor muscles training using pressure biofeedback on pain and disability of school teachers with neck pain. J Phys Ther Sci. 2013;25:657-661.

21. Jull GA, Falla D, Vicenzino B, Hodges PW. The effect of therapeutic exercise on activation of the deep cervical flexor muscles in people with chronic neck pain. Man Ther. 2009;14:696-701.

22. McLean SM, May S, Klaber-Moffett J, Sharp DM, Gardiner E.Risk factors for the onset of non-specific neck pain: A systematic review. J Epidemiol Community Health. 2010;64:565-572.
23. Patrick K, Marshall SJ, Davila EP, Kolodziejczyk JK, Fowler JH, Calfas KJ, Huang JS, Rock CL, Griswold WG, Gupta A, Merchant G, Norman GJ, Raab F, Donohue MC, Fogg BJ, Robinson TN. Design and implementation of a randomized controlled social and mobile weight loss trial for young adults (project SMART). Contemp Clin Trials. 2014;37:10-18.

24. Sun F, Wang LJ, Wang L. Effects of weight management program on postural stability and neuromuscular function among obese children: Study protocol for a randomized controlled trial. Trials. 2015;16:143. 